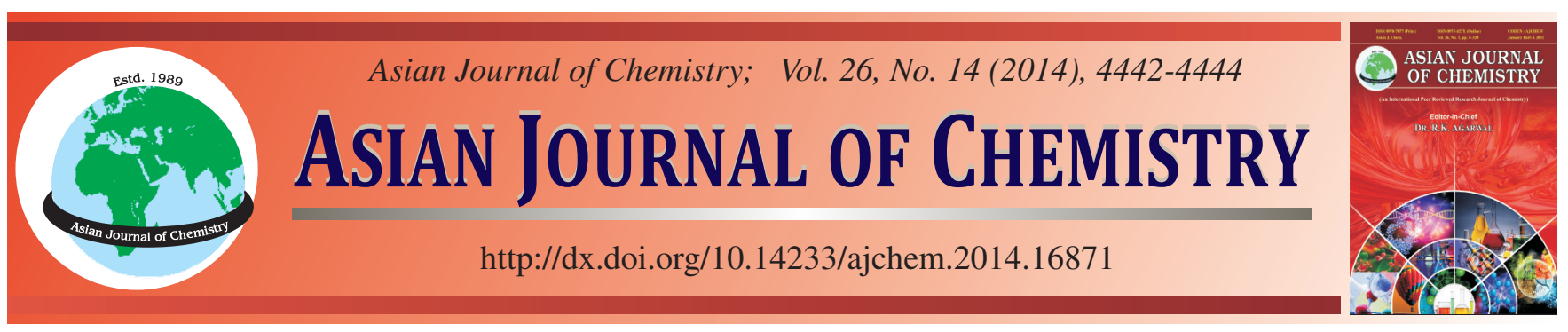

\title{
Determination of Trace Zinc in Water by Flame Atomic Absorption Spectrometry After Preconcentration by Modified Organobentonite with 1-(2-Pyridylazo)-2-naphthol
}

\begin{abstract}
Ying Wang, GuANG Jun Ren and Dong Zhang*
School of Environmental and Chemical Engineering, Shenyang Ligong University, Shenyang 110159, P.R. China

*Corresponding author: Tel./Fax: +86 24 24680345; E-mail: sylgdxdong@sina.com

Received: 13 December 2013;

Accepted: 2 April 2014;

Published online: 5 July 2014;

AJC-15492

A new solid-phase extraction method is described for the determination of traces of zinc in water samples by flame atomic absorption spectrophotometry. The method is based on sorption of zinc ion on the 1-(2-pyridylazo)-2-naphthol modified organobentonite (PAN-Obentonite). And the possible parameters influencing the enrichment and separation were optimized. In the medium of $\mathrm{pH} 6$, the adsorption time was $0.5 \mathrm{~h}$ and capacity of adsorption was $3.8 \mathrm{mg} / \mathrm{g}$. The zinc ion adsorbed on the sorbent could be completely eluated by using $5 \mathrm{~mL}$ of $1 \mathrm{~g} / \mathrm{L}$ of EDTA solution. And a novel method for the determination of trace zinc in water by flame atomic absorption spectrometry after preconcentration with PAN-O-bentonite was established. The enrichment factor was more than 100 . Under the optimal solid-phase extraction conditions, the method detection limit was $0.031 \mathrm{ug} / \mathrm{L}$ with preconcentrated for 100 times. The established method has been successfully applied to analyze well water and tap water sample, the RSD $(n=6)$ within $2.71 \%$. The recoveries were in the range of 93.65 to $101.7 \%$. Compared with other solid phase extraction agent, this method has high sensitivity, better selectivity and lower cost.
\end{abstract}

Keywords: Organobentonite, 1-(2-Pyridylazo)-2-naphthol, Zinc, Solid-phase extraction, Flame atomic absorption spectrometry.

ᄂ _ _ _ _ _ _ _ _ _ _ _ _ _ _ _ _ _ _ _ _ _ _ _ _ _ _ _ - - - - -

\section{INTRODUCTION}

Zinc is an indispensable beneficial element to human life. However, zinc can be accumulated in the tissues of human, animals and plants and it has certain toxicity at high concentration. At present, the methods for determining zinc ion mainly include spectrophotometry, atomic absorption spectrometry and ICP-AES ${ }^{1}$. For low concentration and high saline samples, enrichment and separation are also needed.

So, a pre-concentration and separation procedure is often required. The widely used techniques for the preconcentration and separation include solvent extraction ${ }^{2-5}$, ion-exchange ${ }^{6}$, co- $^{-}$ precipitation $^{5}$ and solid phase extraction $(\mathrm{SPE})^{5,7-11}$, etc. In those techniques, in recent years, solid phase extraction (SPE) preconcentration and separation has become increasing popular for the determination of trace level of metals. The main solidphase extraction sorbents are ion imprinted polymeric ${ }^{7-9}$, nano titanate powder, include nano-calcium titanate powder ${ }^{12}$, nanobarium-strontium titanate powder ${ }^{13}$, nano-barium titanate ${ }^{14}$ and nanoparticulate metal oxides, such as $\mathrm{TiO}_{2}{ }^{15}$, have been found to have very high adsorption capacity of heavy metal ions from environmental samples. However, the cost for all adsorbents is very high.

Bentonite, as a common and low cost material with large specific surface area and good adsorbency, has been used in environmental area ${ }^{16-18}$. But it also possesses high hygroscopic property which made it easily swell into gelatinous serous fluid when contacting water, so it can not be used as a material for adsorption preconcentration and separation. When its surface is modified, however, its performance can be improved. In our foregone research, after modified by cetyltrimethylammonium bromide (CTMAB), the surface of bentonite is modified by dithizone and 1-(2-pyridylazo)-2-naphthol ${ }^{19,20}$. But the 1-(2pyridylazo)-2-naphthol modified organobentonite (PAN-Obentonite) use in pre-concentration and separation of zinc ion has not been studied. In this work, the adsorptive potential of PAN-O-bentonite for $\mathrm{Zn}$ ion was assessed using the batch adsorption method. A new method using PAN-O-bentonite as solid-phase extraction agent has been developed for the enrichment and separation of trace $\mathrm{Zn}$ ion in pipe network water and river water samples analyses by FAAS.

\section{EXPERIMENTAL}

Main equipment and reagents: WYX9003A atomic absorption spectrophotometer (Shenyang Analytical Instrument Factory).

Organobentonite, according to reference ${ }^{20}$, bentonite (sifted by a 200 mesh screen) which was purified and dried and put into a $300 \mathrm{~mL}$ of CTMAB solution $(50 \mathrm{~g} / \mathrm{L})$. The mixture was heated and stirred in $80^{\circ} \mathrm{C}$ water bath for $2 \mathrm{~h}$. 
After being cooled, it was filtered, washed and baked at $90{ }^{\circ} \mathrm{C}$. By grinding and sifting through a 200 mesh sieve, organobentonite was obtained. Then, $10 \mathrm{~g}$ of organobentonite was submerged into $250 \mathrm{~mL}$ of $2 \mathrm{~g} / \mathrm{L} \mathrm{1-(2-pyridylazo)-2-naphthol}$ absolute ethyl alcohol solution. The mixture was stirred for 15 min away from the sunshine in a $60^{\circ} \mathrm{C}$ water bath. Afterwards, it was kept still and left for $0.5 \mathrm{~h}$. It was filtered again and dried at $40{ }^{\circ} \mathrm{C}$ and left for $24 \mathrm{~h}$. After being cooled, organobentonite modified by 1-(2-pyridylazo)-2-naphthol (PAN-Obentonite) was obtained and put into a brown bottle.

Standard stock solution of zinc: $0.1 \mathrm{~g} / \mathrm{L}$; Into a $250 \mathrm{~mL}$ beaker, $0.1000 \mathrm{~g}$ of high-pure metal zinc and $20 \mathrm{~mL}$ of $\mathrm{HCl}$ $(6 \mathrm{~mol} / \mathrm{L})$ were added. The solution was heated to dissolve the sample completely. After cooling, it was diluted to a $1000 \mathrm{~mL}$ volumetric flask. The prepared solution was diluted to the required concentration when used. Water at different $\mathrm{pH}$ was prepared on $\mathrm{pH}$-meter with diluted nitric acid or ammonia water.

All the reagents were analytically pure except for special remarks. The water in this study was distilled water.

Static adsorption experiment: A certain amount of zinc solution was put into a $50 \mathrm{~mL}$ colourimetric cylinder with stopper and diluted to the mark with water at $\mathrm{pH} 6$. After that, $0.1 \mathrm{~g}$ of PAN- $O$-bentonite was added. The mixture was sealed, oscillated and adsorbed at constant temperature for $0.5 \mathrm{~h}$, after which it was centrifugated and separated. The content of $\mathrm{Zn}^{2+}$ in supernate was measured and the adsorptive capacity was calculated.

Elution experiment: Based on the procedure in static adsorption experiment, the supernate was discarded. The mixture was washed twice with water at a $\mathrm{pH}$ of 6 and $5 \mathrm{~mL}$ of $1 \mathrm{~g} / \mathrm{L}$ EDTA solution was added. Thereafter, it was oscillated, eluted, centrifugated and separated. The content of $\mathrm{Zn}^{2+}$ in eluent was measured and the recovery was calculated.

\section{RESULTS AND DISCUSSION}

Effect of pH on the adsorption capacity of zinc ion: 50 $\mu \mathrm{g}$ of $\mathrm{Zn}^{2+}$ was decanted into a $50 \mathrm{~mL}$ volumetric flask with water at different $\mathrm{pH}$ values. According to the adsorption experiment method, the adsorption capacity was measured and the adsorption rate was calculated. The results showed that the adsorption rate was affected by $\mathrm{pH}$ value and it grew with the rise of $\mathrm{pH}$ value. When $\mathrm{pH}$ value was 5-9, adsorption capacity reached maximum. When $\mathrm{pH}$ value was over 8 , deposits was generated, affecting the adsorption. So, in this experiment $\mathrm{pH}$ value was 6 (Fig. 1).

Effect of oscillation adsorption duration on adsorption capacity: Adsorption capacity was measured with different oscillation adsorption duration. The results showed that adsorption reached equilibrium in the main with oscillation for $25 \mathrm{~min}$ and when the oscillation duration was lengthened, the adsorption changed little (Fig. 2). So in this experiment the duration of $0.5 \mathrm{~h}$ was chosen to ensure sufficient adsorption.

Elution experiment and stability of adsorbent: When adsorption condition was optimized, $\mathrm{Zn}^{2+}$ was eluted with $5 \mathrm{~mL}$ of $\mathrm{HNO}_{3}(0.05-2.5 \mathrm{~mol} / \mathrm{L})$ or EDTA solution $(0.25-2.5 \mathrm{~g} / \mathrm{L})$ of different concentrations and the recovery was calculated. The results showed the elution effect was optimal on condition that $5 \mathrm{~mL}$ of $1 \mathrm{~g} / \mathrm{L}$ of EDTA solution was employed as elution

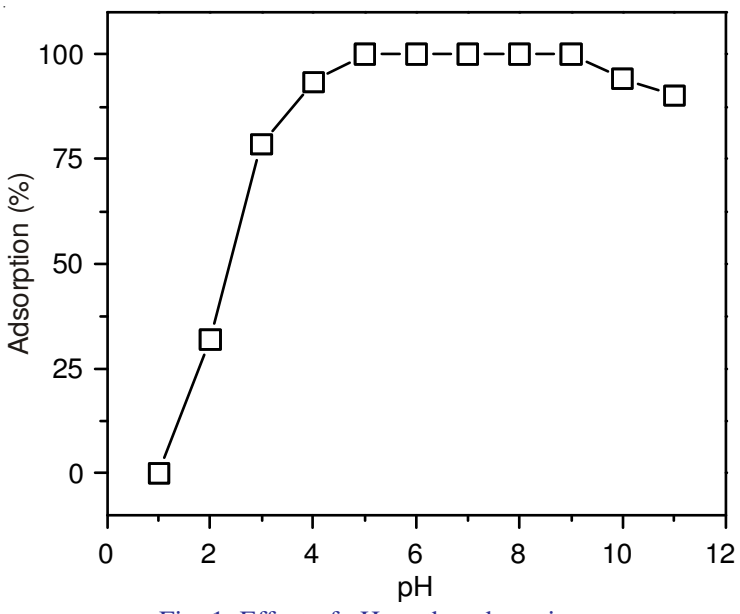

Fig. 1. Effect of $\mathrm{pH}$ on the adsorption

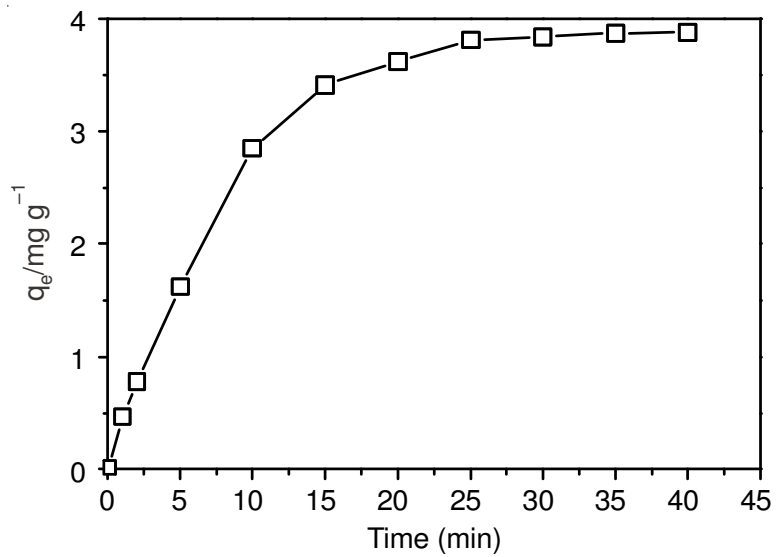

Fig. 2. Effect of contact time on $\mathrm{Zn}^{2+}$ adsorption

with oscillation for $5 \mathrm{~min}$ and the recovery reached up to $98.1 \%$. Meanwhile, all the recoveries of elution were below $95 \%$ with $\mathrm{HNO}_{3}$ solution used. So $5 \mathrm{~mL}$ of $1 \mathrm{~g} / \mathrm{L}$ of EDTA solution was used and the oscillation elution duration was $5 \mathrm{~min}$.

Under experimental condition, the supernatant kept colourless and clear. After elution, when the adsorbent was dried in oven at $40{ }^{\circ} \mathrm{C}$ and then used repeatedly, its adsorption capacity was constant. It indicated that $\mathrm{PAN}-\mathrm{O}$-bentonite was stable.

Static adsorption capacity: Adsorption experiment method was conducted and the initial solution was changed. When the initial solution of $\mathrm{Zn}^{2+}$ was $4 \mathrm{mg} / \mathrm{L}$, adsorption rate was $100 \%$ with static adsorption capacity of $2 \mathrm{mg} / \mathrm{g}$. The adsorption rate declined with the increase of the initial concentration of $\mathrm{Zn}^{2+}$ and when the initial concentration of $\mathrm{Zn}^{2+}$ reached up to $8 \mathrm{mg} / \mathrm{L}$, the adsorption rate was $95 \%$ with static adsorption capacity of $3.8 \mathrm{mg} / \mathrm{g}$.

Detection limit and precision: In order to studied the possibility of pre-concentration low concentrations of $\mathrm{Zn}$ ion from large volumes, $1 \mu \mathrm{g}$ of $\mathrm{Zn}^{2+}$ was dissolved in various volume (including 20, 50, 100, 200, 300, 400 and $500 \mathrm{~mL}$ ) of water together. After adsorption, the PAN- $O$-bentonite were eluted with $5 \mathrm{~mL}$ of EDTA solution. The amounts recovered are listed in Table-1. It could be seen that when the solution volume was $500 \mathrm{~mL}$, the recovery was above $90 \%$. The enrichment factor was 100 .

After preconcentration for 100 times with $\mathrm{PAN}-\mathrm{O}$-bentonite, detection limit (3a) was $0.031 \mu \mathrm{g} / \mathrm{L}$. The sensitivity is 140 and 


\begin{tabular}{|c|c|c|c|}
\hline \multicolumn{4}{|c|}{ DETERMINATION OF ZINC I } \\
\hline Samples & \multicolumn{2}{|c|}{ Found $\left(\mu \mathrm{g} \mathrm{L}^{-1}\right)$} & RSD $(\%)$ \\
\hline Tap water sample & \multicolumn{2}{|c|}{9.34} & 2.71 \\
\hline Well water sample & \multicolumn{2}{|c|}{22.51} & 3.05 \\
\hline River water sample & \multicolumn{2}{|c|}{80.60} & 1.95 \\
\hline \multicolumn{4}{|c|}{$\begin{array}{c}\text { TABLE-1 } \\
\text { PRECONCENTRATION AND RECOVERY OF ZINC }\end{array}$} \\
\hline $\begin{array}{l}\text { Volume of the } \\
\text { solution }(\mathrm{mL})\end{array}$ & $\begin{array}{l}\text { Quantity in } \\
\text { eluent }(\mu \mathrm{g})\end{array}$ & $\begin{array}{l}\text { Recovery } \\
(\%)\end{array}$ & $\begin{array}{l}\text { Enrichment } \\
\quad \text { factor }\end{array}$ \\
\hline 20 & 0.983 & 98.3 & 4 \\
\hline 50 & 0.975 & 97.5 & 10 \\
\hline 100 & 0.992 & 99.2 & 20 \\
\hline 200 & 0.966 & 96.6 & 40 \\
\hline 300 & 0.931 & 93.1 & 60 \\
\hline 400 & 0.924 & 92.4 & 80 \\
\hline 500 & 0.917 & 91.7 & 100 \\
\hline
\end{tabular}

15 times higher than the nano barium strontium titanate ${ }^{13}$ and nano barium titanate ${ }^{14}$, respectively. Compared with ion imprinting resin reported in literatures ${ }^{8}$, it is 10 times higher. The $\mathrm{Zn}^{2+}$ solution with initial contration of $0.01 \mathrm{mg} / \mathrm{L}$ was adsorbed and determined for 11 times with relative standard deviation of $2.78 \%$ obtained.

Influence of coexistent ions: $1 \mu \mathrm{g}$ of $\mathrm{Zn}^{2+}$ was added to a series of $50 \mathrm{~mL}$ colourimetric cylinders and different interference ions with various contents were added. The $\mathrm{pH}$ value was regulated and the mixture was decanted to $50 \mathrm{~mL}$ with water at $\mathrm{pH}$ of 5 . Then the mixture was adsorbed and eluted with $0.5 \mathrm{~g}$ of adsorbent added according to experimental method and the recovery was calculated. Controlling the error less than $\pm 5 \%$, the results showed that 2000 times of $\mathrm{Na}^{+}, \mathrm{K}^{+}$, $\mathrm{Cl}^{-}, \mathrm{NO}_{3}{ }^{-}$did not interfere with the test, nor did 1000 times of $\mathrm{NH}_{4}{ }^{+}, \mathrm{Ca}^{2+}, \mathrm{Cr}^{3+}, 500$ times of $\mathrm{PO}_{4}{ }^{3-}, 100$ times of $\mathrm{Cu}^{2+}, \mathrm{Mg}^{2-}$, 50 times of $\mathrm{Al}^{3+}, \mathrm{Cd}^{2+}, \mathrm{Pb}^{2+}$ and $\mathrm{Fe}^{3-}$. The results indicate that the method has a good tolerance to matrix interference. Compared with other reported techniques, the method has higher selectivity of zinc.

Sample analyses: The tap water sample was freshly collected from the water supply of Shenyang City, P.R. China, after allowing the water to flow for $5 \mathrm{~min}$. The well water sample was come from Hui-shan of shenyang and the river water sample was collected from Hun-he River, Shenyang, P.R. China. All water samples were filtered through a $0.45 \mu \mathrm{m}$ membrane filter and analyzed immediately after sampling. At the same time, standard addition recovery test was performed (Table-2). It could be known from the Table-2, that the recoveries were in the range of 93.65 to $101.7 \%$.
TABLE-2

ION IN WATER SAMPLES $(n=6)$

\begin{tabular}{ccc} 
Added $\left(\mu \mathrm{g} \mathrm{L}^{-1}\right)$ & Recovered $\left(\mu \mathrm{g} \mathrm{L}^{-1}\right)$ & Recovery $(\%)$ \\
5 & 14.26 & 98.40 \\
10 & 19.51 & 101.7 \\
20 & 29.17 & 99.15 \\
5 & 27.46 & 99.00 \\
10 & 32.58 & 100.70 \\
20 & 41.64 & 95.65 \\
20 & 99.33 & 93.65 \\
50 & 129.65 & 98.10 \\
100 & 175.82 & 95.22 \\
\hline
\end{tabular}

\section{Conclusion}

PAN-O-bentonite has been successfully applied in preconcentration/separation procedure for the determination of zinc in water samples. The sorbent showed high capacity and relevant preconcentration factor. The high tolerance to interfering substances has presented advantage towards the sorbent. The recovery results for real samples were satisfactory. Compared with ion imprinting resin and nano powder solid phase extraction agent, this method has high sensitivity, better selectivity and lower cost.

\section{REFERENCES}

1. State Environmental Protection Administration of China, Analysis Method of Water and Wastewater, China Environmental Science Press, Inc. Beijing, edn 4 (2002).

2. A. Mellah and D. Benachour, Chem. Eng. Prog., 45, 684 (2006).

3. A. Mellah and D. Benachour, Sep. Purif. Technol., 56, 220 (2007).

4. M.K. Jha, D. Gupta, P.K. Choubey, V. Kumar, J. Jeong and J. Lee, Sep. Purif. Technol., 122, 119 (2014).

5. I. Komjarova and R. Blust, Anal. Chim. Acta, 576, 221 (2006)

6. P.E. Franco, M.T. Veit, C.E. Borba, G.C. Gonçalves, M.R. FagundesKlen, R. Bergamasco, E.A. da Silva and P.Y.R. Suzaki, Chem. Eng. J., 221, 426 (2013).

7. M. Behbahani, M. Salarian, A. Bagheri, H. Tabani, F. Omidi, A. Fakhari. J. Food Comp. Anal., 34, 81 (2014).

8. M. Shamsipur, H.R. Rajabi, S.M. Pourmortazavi and M. Roushani, Spectrochim. Acta A, 117, 24 (2014).

9. F. Shakerian, S. Dadfarnia and A.M.H. Shabani, Food Chem., 134, 488 (2012).

10. M. Ghaedi, K. Niknam, K. Taheri, H. Hossainian and M. Soylak, Food Chem. Toxicol., 48, 891 (2010).

11. M. Ghaedi, K. Mortazavi, M. Montazerozohori, A. Shokrollahi and M. Soylak, Mater. Sci. Eng. C, 33, 2338 (2013).

12. D. Zhang and P. Hou, Acta Chim. Sin., 67, 1336 (2009).

13. D. Zhang, X. Guan and H. Gao, Metal. Anal., 28, 38 (2008).

14. D. Zhang and Y. Cheng, Asian J. Chem., 25, 3172 (2013).

15. N. Pourreza, S. Rastegarzadeh and A. Larki, J. Ind. Eng. Chem., 20, 127 (2014).

16. S.S. Tahir and R. Naseem, Sep. Purif. Technol., 53, 312 (2007).

17. M. Önal and Y. Sarikaya, Powder Technol., 172, 14 (2007).

18. V.G. Mihucz, C.J. Done, E. Tatár, I. Virág, G. Záray and E.G. Baiulescu, Talanta, 70, 984 (2006).

19. D. Zhang and G.S. Zhao, Asian J. Chem., 25, 9739 (2013).

20. D. Zhang, L.Z. Xu and G.J. Ren, Phys. Test. Chem. Anal. B, 45, 1163 (2009). 